\title{
The Roadmap Design of Natural Tourism Based on the Ecopreneurship Concept to Achieve the Sustainable Development Goals 2030 Agenda (Case on Joben Ecopark, Indonesia)
}

\author{
Yassir Aulia $^{\# 1}$, Ratna Lindawati Lubis Nugroho ${ }^{* 2}$ \\ ${ }^{\text {\#} S c h o o l ~ o f ~ E c o n o m i c s ~ a n d ~ B u s i n e s s, ~ T e l k o m ~ U n i v e r s i t y ~}$ \\ Bandung, Indonesia
}

\begin{abstract}
The Mount Rinjani National Park has many potentials in creating jobs, promoting local products and socio-cultures. Natural tourism is an option of alternative tourism in which its management can be realized based on three aspects, i.e., social, economic, and environmental values. These are three supporting factors of the Ecopreneurship concept (Triple Drivers of Ecopreneurship). One of the tourism destinations at the Mount Rinjani National Park is Joben Ecopark. Therefore, as an initial step in developing natural tourism based on the ecopreneurship concept at the Mount Rinjani National Park is to create a roadmap design of Joben Ecopark of 2020-2023. This study used a qualitative method with parties related to Joben Ecopark, i.e., Mount Rinjani National Park Office, Joben Village people, and the Regional Government of the West Nusa Tenggara Province. The study results demonstrated that the Mount Rinjani National Park Office Program in actualizing SDGs target 8.9 based on the ecopreneurship concept at Joben Ecopark has not implemented technical review and arranged the object development master plan. Also, public participation in promoting local products and cultures based on the ecopreneurship concept at Joben Ecopark has not maximized due to the absence of programs from related parties. Therefore, this study created a roadmap design of Joben Ecopark based on the ecopreneurship concept of 2020-2023 arranged in a new normal tourism lifestyle to achieve SGDs 2030 target 8.9. The roadmap design of Joben Ecopark is tourism object design, tourism destination development, institutional and human resource capacity improvement, building creative tourism industries, and enhancing natural tourism promotions at Joben Ecopark.
\end{abstract}

Keywords - Ecopreneurship, Joben, Roadmap, New Normal.

\section{INTRODUCTION}

SDGs are the commitment of worldwide countries to implement the 2030 agenda, i.e., sustainable development. SDGs indicators are applicable to measure developments at the global, national, and regional levels. Globally, regional SGDs will provide an idea of development advances in a region that is comparable with the development outcomes at a global scale [4]. The SDGs conference resulted in 17 objectives, 169 targets, and 241 indicators.

One of the 169 targets of the Indonesian government is to achieve SDGs target 8.9, i.e., "devise and implement policies to promote sustainable tourism that creates jobs and promotes local culture and products" [14]. One of the prioritized tourism destinations in Indonesia in supporting sustainable tourism is at the Mount Rinjani National Park in West Nusa Tenggara.

The Mount Rinjani National Park (Indonesian: TNGR which stands for Taman Nasional Gunung Rinjani) has an iconic tourism appeal, i.e., Mount Rinjani, inviting tourists to visit and climb the mountain. The massive appeal of Mount Rinjani is observed from the increasing number of tourists annually. Economic conditions of local communities in villages surrounding the TNGR area are driven by several sectors, e.g., trekking service. It is a promising activity and livelihood for local communities. It is because tourism activities have long developed in the TNGR area. Almost all tourism jobs in the area are related to trekking Mount Rinjani. Trekking Mount Rinjani is a favorable tourism activity. However, trekking negatively impacts the environment, including 


\section{DOI: $10.51386 / 25815946 /$ ijsms-v4i6p108}

generating plastic wastes carried out by trekkers, disrupting flora and fauna habitats in Mount Rinjani. In 2016, a Komunitas Sapu Gunung Indonesia survey revealed that the average waste carried out by tourists/visitors to the Mount Rinjani National Park was 160.24 tons/year or three kg/person [12]. Based on the TNGR Office data, in 2017, wastes in Mount Rinjani amounted to $13,679.51 \mathrm{~kg}$. In detail, 7,835 kg at Senaru and 6,299 $\mathrm{kg}$ at Sembalun. Meanwhile, in 2018, the wastes amounted to 3,980 kg. Wastes exited at Senaru were 2,371.5 kg and $1,608.5 \mathrm{~kg}$ at Sembalun [15].

Tourist visits to the Mount Rinjani National Park area, primarily at the Mount Rinjani, cause a pile of trash damaging the ecosystem. Nonetheless, if such wastes can be managed well, positive effects will be perceived on the surrounding community's economy since the economy is a vital factor in encouraging productivity. The phenomena inhibiting productivity are non-optimal waste management such as land and forest fires and the COVID-19 outbreak limiting all activities in the socioeconomic and other aspects.

From the phenomena at the Mount Rinjani National Park, the researchers were enticed to a study by [5] since tourism management is required at the Mount Rinjani National Park area towards alternative tourism based on environmental, social, and economic values. Natural tourism is an option of alternative tourism in which the management can be realized based on three aspects, i.e., social, economic, and environmental values. These are three supporting factors of the Ecopreneurship concept (Triple Drivers of Ecopreneurship) [5].

An initial step in developing natural tourism based on the ecopreneurship concept at the Mount Rinjani National Park area is creating a roadmap design for 2020-2023. The authors arranged a roadmap design of 20202023 to adjust to the SDGs regional action plan (RAD) of West Nusa Tenggara of 2019-2020. The roadmap design consists of the mission, programs, and management activities of natural tourism objects based on the ecopreneurship concept with three values, i.e., environmental, social, and economical. Natural tourism development based on the ecopreneurship concept will positively impact jobs, preserve socio-cultures, and increase productivity.

From the occurring phenomena, the authors selected Joben Ecopark as the study object due to various factors, such as a tourism object newly developed at the end of 2019 and involving the public in its management. Another factor is because Joben Ecopark implements an environmentally friendly system for visitors, where they are forbidden to bring outside food to reduce plastic or single-use material consumption.

\section{LiterATURE REVIEW}

\section{A. Roadmap}

A roadmap is a direction for development measures that are strategic, large-scale, and lengthy. The roadmap essence is development paths, which will bring the actors to acquire the development goals if carried out properly. These paths are designed as such by considering various factors adhering to the context, situation, and development environment. Therefore, it leads to goal achievement with high effectiveness and efficiency levels. Effectiveness and efficiency are obtained through a measured and systematic development process. There are three fundamental principles in arranging development steps and stages, i.e., realistic planning, measured implementation, and maintained sustainability between activities [13].

\section{B. Ecopreneurship}

The word "ecopreneur" in ecopreneurship comes from a two-word combination, i.e., 'ecological' (eco) and 'entrepreneur,' abbreviated to ecopreneur. The word ecopreneur refers to entrepreneurs observing business potentials in the environment field, called green business [11]. Ecopreneur is categorized into two: "environmentally conscious entrepreneurs" who are those aware of environmental issues but not running an environmental-based business, and "green entrepreneurs" who are those aware of environmental issues and running an environmental-based business [16]. Thus, ecopreneurship refers to business activities considering the ecosystem and environmental sustainability to preserve the environment and run the economy well.

\section{Sustainable Tourism with the Ecopreneurship Concept}

Sustainability principles refer to communities' environmental, economic, and sociocultural aspects in building the tourism sector and balance. It follows the ecopreneurship concept based on three values explained by the authors. Three ecopreneurship concepts should form sustainable tourism to guarantee its long-term sustainability. 
The principles of sustainable tourism with the ecopreneurship concept comprise social, economic, and environmental values. These values are adapted from [6]. Three ecopreneurship values are portrayed to achieve sustainable tourism by involving local community participation, environment conservation, and local culture and product preservation to increase public income in the SGDs 2030 goal framework.

\section{A. Research Model}

\section{III.METHODOLOGY}

This study involved parties related to the eco-based tourism development or natural tourism, explaining the ecopreneurship concept, i.e., environmental, social, and economic values [6]. The Joben Ecopark Roadmap Design 2020-2023 was observed for its association in achieving Sustainable Development Goals 2030 in sustainable tourism that creates jobs and promotes local cultures and products (target 8.9). This study research model is shown in Fig. 1.

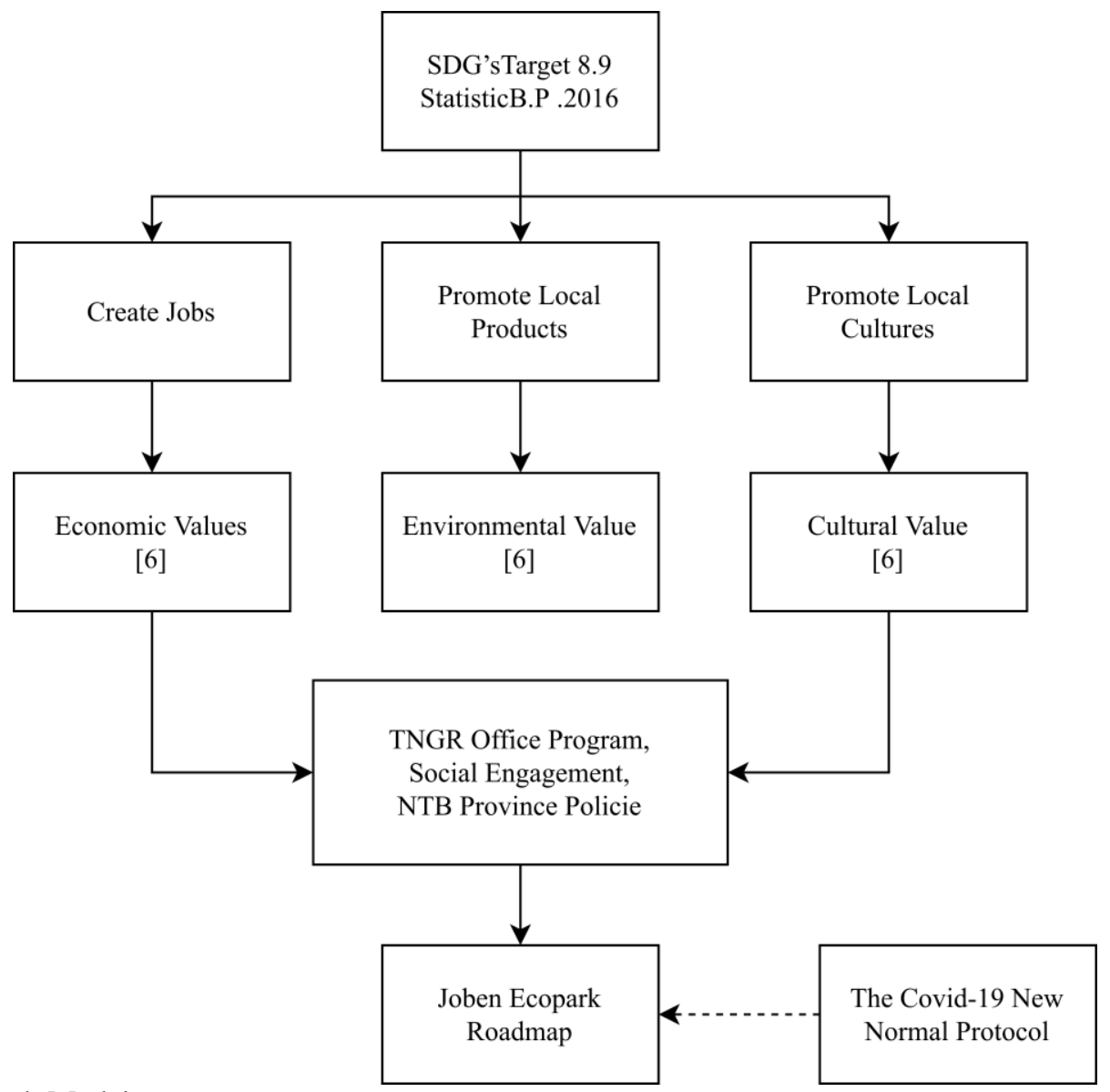

Fig. 1 Research Model

\section{B. Data Source}

Primary data are acquired from observation of research results on the field. Primary data sources are interviewees or respondents related to the study object to obtain information or data. Primary data are obtained via interviewees by introducing themselves, interview goals, and asking permission to document the interview process [8]. This study interviewed interviewees and respondents from different viewpoints. In the initial stage, researchers asked questions on the study and expected answers from respondents concerning individual perceptions related to the study object's condition. The interview was conducted on Joben Ecopark management, which is in its initial management stage by related parties. 
Besides utilizing primary data, this study is also supported by secondary data obtained or collected by researchers from available sources. It aims to enhance the findings and complete information acquired from primary data [3].

\section{Data Analysis Technique}

Data analysis in a qualitative study is a systematic tracking and set of field notes obtained from the interview, observation, and other sources, allowing the researchers to report study results. Data analysis includes organizing, solving, synthesis, pattern-seeking, and determining parts to be reported following the study focus. Data analysis is performed sustainably, continuously, and repetitively [1]. This study employed the Miles and Huberman [7], analysis technique explained as follows:

\section{a. Pre-Research Analysis}

Data analysis before the researchers enter the field is performed on data of preliminary study results or secondary data. It will be used to determine the study focus. However, this study focus is temporary and will be developed after the researchers are in the field.

\section{b. Miles and Huberman On-Field Analysis Model}

An analysis of answers proposed during the interview has been performed before conducting the interview. If the answer suggested by the interviewee during the interview is unsatisfactory, the said question will be continued to a particular stage to acquire credible information. The data analysis in a qualitative study is performed during data collection and after collecting data in a specific period. The Miles and Huberman model [7], states that activities in qualitative data analysis are interactive and continuous on each study stage until it is finished.

\section{IV.RESULT AND DISCUSSION}

\section{A. The Mount Rinjani National Park Office Program to Manage Natural Tourism at Joben Ecopark Based on The Ecopreneurship Concept}

The program carried out by the Mount Rinjani National Park Office in managing and developing Joben Ecopark based on the ecopreneurship concept can be examined in an interview excerpt between the author and the Head of SPW II Mount Rinjani National Park and the Head of Joben Resort. The study results revealed that the Mount Rinjani National Park Office (BTNGR) Program was not maximally managing the eco-park based on the ecopreneurship concept to achieve the SDGs 8.9 goal. It is due to the absence of technical review and plan from BTNGR. The BTNGR management continues to coordinate and agree with the East Lombok Regency regional government to arrange a master plan of Joben tourism development.

\section{B. Social Engagement in Natural Tourism at Joben Ecopark Based on The Ecopreneurship Concept}

Social engagement in managing natural tourism based on the ecopreneurship concept at Joben Ecopark can be observed in the interview excerpt between the author and the representative of Joben Ecopark social community manager. The study results demonstrated that the social community manager remains to manage Joben Ecopark voluntary since there are no budget and program interventions from BTNGR and the East Lombok Regency regional government. Moreover, in promoting local products and cultures, the people make souvenirs from natural products and still follow their parents' culture. The Joben Village people expect that the agreement between BTNGR and the East Lombok Regency regional government involves surrounding communities to augment their income and provide jobs from the Joben Ecopark tourism object management.

\section{Regional Government Policies to Develop Natural Tourism at Joben Ecopark Based on The Ecopreneurship Concept}

The study presented the study results by interviewing the Head of East Lombok Regency Tourism Department to discover regional government policies to develop natural tourism at Joben Ecopark based on the ecopreneurship concept. The study results suggested no regional policies in developing natural tourism based on the ecopreneurship concept at Joben Ecopark since there is no planning review or master plan of the local tourism development (Regency Ripparda). It is caused by the overlapping management of tourism objects with the private sector was only resolved in early 2020 .

The East Lombok Regency regional government, i.e., East Lombok Regency Tourism Department, is currently establishing cooperation with the Sekolah Tinggi Pariwisata Mataram (STP Mataram) in formulating 


\section{DOI: $10.51386 / 25815946 /$ ijsms-v4i6p108}

the master plan of East Lombok Regency local tourism. The East Lombok Regency regional development will be authorized into a regional government (Perda) by the end of 2020 and will be issued as the guideline in constructing and developing East Lombok Regency tourism and at Joben Ecopark.

The study utilized the NTB province regional development plan of 2013-2018 as the natural tourism development guideline based on the ecopreneurship concept at Joben Ecopark. The authors used Ripparda of NTB Province because Article 4 paragraph 1, Ripparda is stated as the guideline for local tourism development, and Article 4 paragraph 2 states that Ripparda is the guideline for arranging the Regency/City Tourism Development Master plan.

Local tourism development in Chapter II Ripparda of NTB Province of 2013-2018 [9], has four development objectives, set as the reference in developing natural tourism based on the ecopreneurship concept at Joben Ecopark to achieve SDGs target 8.9. The government policy to promote a green economy should ensure a fair transition for workers from less environmentally friendly industries. It is in line with the observation digitally performed by the authors through an online course held by the One United Nations Climate Change Learning Partnership [2].

\section{The Relationship of Joben Ecopark Roadmap Design of 2020-2023 and SDGs 2030 Target 8.9 Achievement}

Based on the study results through identifying problems and interviewing stakeholders and interviewees, it was discovered that the relationship between Joben Ecopark roadmap design and SDGs target 8.9 achievements is promoting sustainable tourism that creates jobs and promotes local products and cultures. The study results showed the relationship between SDGs target 8.9 and Joben Ecopark roadmap design 2020-2023. The ecopreneurship concept was designed to be the program and priority activity to manage and develop Joben Ecopark tourism object from 2020-2023 following the observation and interview results between the author and related parties, i.e., Mount Rinjani National Park Office, East Lombok Regency Tourism Department, and the representative of Joben Ecopark social community manager.

The Joben Ecopark roadmap design 2020-2023 refers to the regional tourism development, i.e., Ripparda of NTB Province of 2013- 2028, based on 4 (four) leading pillars of local tourism under Regional Regulation No. 7 of 2013, i.e., including constructing tourism destinations, promoting the tourism, tourism industry, and tourism institution. These 4 (four) pillars will be the reference to actualize SDGs 8.9. focusing on increasing tourism in nature will increase economic resources because the concept becomes physical wealth so that the concept of nature becomes a product that can be consumed by the community [10]

\section{E. Joben Ecopark Roadmap Design of 2020-2023 Based on The Ecopreneurship Concept}

Based on the study results via interview, identification, and analysis processes, the outcome of this study is creating a roadmap design based on the ecopreneurship concept of 2020-2023, comprising the mission, program, and priority activities. The roadmap plan arrangement considered the new normal situation, such as operational and management readiness, ensuring a safe/comfortable tourism experience, and rebuilding the trust of tourists or visitors in visiting the TNGR area. The Joben Ecopark roadmap design 2020-2023 is as follows:

Joben Ecopark Roadmap Design of 2020-2023 based on the ecopreneurship concept arranged in the tourism new normal setting consists of priority programs and activities in five management and development missions:

1. Arrange Tourism Object Plan and Improve Coordination Between Parties

2. Construct Tourism Destinations at Joben Ecopark

3. Improve Institutional and Human Resource Capacity of Joben Village

4. Build Tourism Creative Industries at Joben Village

5. Enhance Natural Tourism Promotion of Joben Ecopark

\section{Conclusions}

The study results state that the Mount Rinjani National Park Office program has not implemented a technical review and arranged the destination development master plan. Therefore, BTNRG remains to provide educational assistance to Joben Ecopark communities. Furthermore, social engagement in promoting local products and cultures based on the ecopreneurship concept at Joben Ecopark remains voluntary since there are 


\section{DOI: $10.51386 / 25815946 /$ ijsms-v4i6p108}

no programs from related parties and financial assistance from BTNGR and the Regional Government. Hence. The study referred to RIPPARDA of NTB Province of 2013-2018 based on 4 (four) primary pillars of local tourism under the Regional Regulation No. 7 of 2013, including tourism destination construction, tourism marketing, tourism industry, and tourism institutional. The ecopreneurship concept's environmental, social, and economic value indicators are set into the priority programs of management and development of Joben Ecopark Tourism Object of 2020-2023. It creates a Joben Ecopark roadmap design with the ecopreneurship concept for 2020-2023 arranged in a new normal setting. Thus, it generates priority activities with management and development missions, i.e., Arrange Tourism Object Plan and Improve Coordination Between Parties, Construct Tourism Destinations at Joben Ecopark, Improve Institutional and Human Resource Capacity of Joben Village, Build Tourism Creative Industries at Joben Village, and Enhance Natural Tourism Promotion of Joben Ecopark.

\section{REFERENCES}

[1] Firman. (2010). Analisis Data dalam Penelitian Kualitatif. Bimbingan dan Konseling FIP Universitas Negeri Padang.

[2] Foundation, U. (2019, July 11). 9 REASONS WE NEED PROGRESS ON CLIMATE ACTION AND THE SUSTAINABLE DEVELOPMENT GOALS. Retrieved from https://unfoundation.org/blog/post/9-reasons-we-needprogress-on-climate-action-andthe-sustainable-development-goals.

[3] Hasan, I. M. (2002). Pokok-pokok Materi Metodologi Penelitian dan Aplikasinya. Bogor: Ghalia Indonesia.

[4] Kurtubi, D. A. (2018, March 1). Sustainable Development Goals dan Pembangunan Kesejahteraan Sosial. Retrieved from dinsosriau.go.id.

[5] Lubis, R. (2018). The triple drivers of ecopreneurial action for taking the recycling habits to the next level: a case of bandung city, indonesia. International Journal of Multidisciplinary Thought.

[6] Lubis, R. (2019). The three drivers of ecopreneurial action. International Journal of Multidisciplinary Thought.

[7] Miles, M.B and Hubberman, A.M (1984). Analisis Data Kualitatif. Terjemahan oleh Tjetjep Rohendi Rohidi. 1992. Jakarta: Universitas Indonesia.

[8] Narimawati, U. (2008;98). Metodologi Penelitian Kualitatif dan Kuantitatif. Bandung: Agung Media.

[9] NTB, P. P. (2013). Ripparda Provinsi NTB. Mataram, Nusa Tenggara Barat, Indonesia: Dinas Pariwisata NTB.

[10] Okolo, C.Y and Ogbuefi, J.U. (2021). Traditional Land Tenure System in Nnewi Anambra State, Nigeria. International Journal of Science and Management Studies, Vol 4(6), 1-7.

[11] Pastakia, A. (2002) "Assessing Ecopreneurship in the Context of a Developing Country The case of India”, Greener Management International, 93:108.

[12] Purnomo. (2016). Ada 160 ton sampah di Rinjani,ulah siapa?

[13] Universitas Negeri Semarang. (2012-2015). Mewujudkan Unnes Smart Campus sebagai perguruan Tinggi modern yang sehat, unggul, dan sejahtera.

[14] Statistik, B. P. (2016). Potret Awal Tujuan Pembangunan Berkelanjutan (Sustainable Development Goals) di Indonesia. Jakarta: Badan Pusat Statistik Republik Indonesia.

[15] suarantb. (2018). Kendalikan Sampah, Pendaki Rinjani Dibatasi 700 Orang. suarantb.

[16] Volery, T. (2002). Ecopreneurship: Rationale, current issues and future challenges. In Conference Papers of Swiss Research Institute of Small Business and Entrepreneurship, St. Gallen (Switzerland) (pp. 541-553). 